\title{
Tiga Relief Kharmawibangga Candi Borobudur
}

\author{
Hari Lelono
}

Keywords: temple, relief, Buddha, description, interpretation

\section{How to Cite:}

Lelono, H. Tiga Relief Kharmawibangga Candi Borobudur. Berkala Arkeologi, 15(1), 10-17. https://doi.org/10.30883/jba.v15i1.651

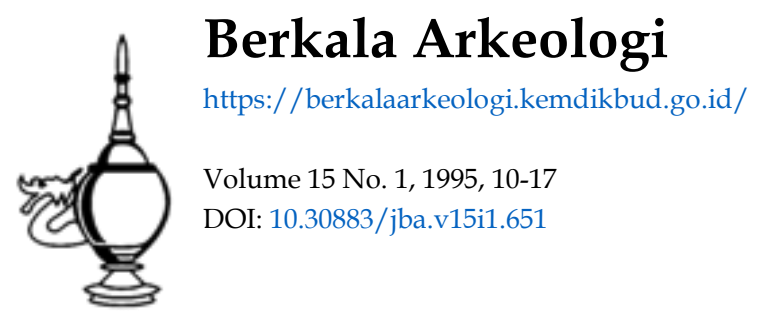

\section{@(@) $\Theta(\odot$}

This work is licensed under a Creative Commons Attribution-NonCommercial-ShareAlike $\underline{4.0 \text { International License. }}$ 


\title{
TIGA RELIEF KHARMAWIBANGGA CANDI BOROBUDUR
}

\author{
T.M. Hari Lelono \\ (Balai Arkeologi Yogyakarta)
}

\section{Pendahuluan}

Menarik perhatian pada dekade ini banyak penelitian arkeologis berkembang untuk mencari jawab permasalahanpermasalahan arkeologis yang belum terpecahkan. Metode penelitian yang semakin berkembang, semakin mempermudah para peneliti dalam memecahkan masalah dan mengembangkan berbagai model dan tipe penelitian. Semua itu dilaku-kan untuk menghasilkan penelitian baik kuantitatif maupun kualitatif de-ngan analisis holistik.

Studi keruangan maupun kawasan telah banyak diacu oleh para peneliti arkeologi generasi masa kini. Dari serangkaian penelitian-penelitian tersebut banyak yang menarik untuk dikaji, salah satunya dalam konteks ini adalah penelitian tentang relief candi. Beberapa skripsi mahasiswa arkeologi FS-UGM cukup menarik untuk ditelaah lebih lanjut, terutama mengenai studi kereliefan.

Studi ruang dalam arkeologi (spatial archaeology) menjangkau berbagai aspek kehidupan manusia masa lalu, baik berkenaan dengan permukiman, tekno-ekonomi, sosio-ekonomi, sosio-politik, organisasi sosial, maupun sistem nilai sebagai hasil kognisi, interaksi dan adapatasi manusia dengan lingkungannya. Tulisan ini mencoba melengkapi apa yang telah dilakukan para peneliti 'pendahulu' dalam kaitannya dengan masalah relief. Pokok bahasan bukan bahasan umum, tetapi bahasan khusus meliputi studi kasus untuk mengungkap fenomena yang dipahatkan pada kaki candi Borobudur, atau lebih dikenal dengan Kharmawibangga.

Bagian kaki candi ini tidak tampak keseluruhan, karena faktor keamanan dan kelestarian candi itu sendiri, sebagai bagian/bahan penguat. Oleh karena itu, tidak semua orang dapat melihat relief tersebut, tetapi dari pustaka karangan arkeolog seperti Van Erp, Soekmono, dan Caspa-ris, berupa rekaman hasil foto dapatlah membantu dalam kajian ini.

Kasus menarik untuk dikaji adalah relief yang menunjukkan ilustrasi kehidupan masyarakat Jawa kuno abad ke $9-10 \mathrm{M}$. Di sinilah tersimpan berbagai adegan pengambaran segi-segi kehidupan masa lampau, anta-ra lain: perilaku keagamaan, pelapisan sosial, mata pencaharian, tata bu- 
sana, peralatan hidup, dan fauna - flora dengan segala macam aspek kehidupan duniawi.

\section{Tiga Relief Menarik Dalam Karmawibhangga.}

Bangunan suci peninggalan agama Budha setinggi $\pm 40 \mathrm{~m}$ itu pada mulanya dipenuhi oleh semak belukar. Pada tahun $1885 \mathrm{JW}$. ljzerman dan rombongan memeriksa kondisi candi itu. Banyak reruntuhan batu ter-sebar tak keruan, dinding dan lantai candi pun ada yang melesak, do-yong, merekah ataupun berlubang. Lebih lanjut mereka memeriksa be-berapa batu di kaki candi, tampak sebuah batu berrelief indah. ljzerman serta merta bersemangat, meminta membongkar lebih lanjut barisan batu bergambar di kaki candi itu (Santiko, Hariani, 1989:13).

Kamadhatu merupakan bagian terbawah dari bangunan tersebut yạng terpahat relief Karmawibhangga terdiri dari 160 panil. Ajaran dari naskah Maha Karmawibhangga, berisikan ajaran sebab dan akibat sega-la perilaku - perbuatan manusia. Secara tegas dinyatakan bahwa suatu perbuatan pasti ada akibatnya, perbuatan baik akan memperoleh kebaikan, sedangkan perbuatan jahat akan menerima karmanya.

Penggambaran relief masih menjadi pro dan kontra tentang pengaruh budaya mana yang lebih dominan dalam kehidupan masyarakatnya. Sylvain Levi (1929), sarjana dari Perancis menyatakan relief karmawibhangga di Borobudur, sesuai dengan isi naskah versi Sansekerta dengan terjemahan versi Cina. August Jan Bernet Kempers berdasarkan pengamatan 23 panil ringkasan Maha Karmawibhangga, menyatakan 85 persen relief tersebut khas Jawa Kuno (Rangkuti, Nurhadi, 1989: 81).

Terlepas dari kontra persepsi antara peneliti asing tersebut, suatu fakta penting pada dasarnya manusia mempunyai keinginan yang dipengaruhi oleh alam lingkungan sekitar untuk mengekspresikan diri dalam segala bentuk. Bentuk tersebut berupa teknologi, ilmu pengetahuan maupun kesenian, dalam konteks ini adalah relief. Semua itu tidak terlepas dari sistem nilai budaya yang ada pada masa Jawa kuno sehingga mempengaruhi segala aspek kehidupan masyarakat. Sistem nilai budaya merupakan konsepsi-konsepsi alam pikiran masyarakat, sehingga mempengaruhi hal-hal yang mereka anggap bernilai dalam hidup. Karena itu, suatu sistem nilai budaya biasanya berfungsi sebagai pedoman tertinggi bagi kelakuan manusia (Koentjaraningrat,1979:32). Oleh karena itu, diperoleh impresi bahwa penggambaran relief tersebut kemungkinan besar mendapat pengaruh yang kuat dari kondisi pada masa itu, paling tidak ada percampuran budaya asal dengan budaya lokal, bahkan mungkin terjadi 
perpaduan dua atu lebih dari kebudayuaan, kemudian menjadi satu kebudayaan baru tanpa adanya unsur-unsur paksaan (asimilasi).

Menarik perhatian dari 160 panil yang mengisahkan kehidupan masyarakat masa lalu, adalah peranan tokoh-tokoh suci, pendeta dan para bhiksu. Kehidupan mereka mendapat perhatian yang sangat besar dari segala macam lapisan masyarakat, dari golongan raja, bangsawan, dan rakyat jelata selalu mengadakan kontak/komunikasi dalam berbagai bentuk. Interaksi tersebut tidak hanya melibatkan orang dewasa, tetapi juga melibatkan anak-anak. Di sisi lain diperlihatkan pula peran para wanita dalam berinteraksi dengan para pendeta, dan bhiksu. Hal tersebut rupanya menunjukkan suatu fenomena tersendiri, bahwa kaum hawa (wanita) sejak masa Jawa kuno sudah besar peranannya dalam kehidupan keluarga sehari-hari. Kehidupan wanita tidak saja hanya untuk melayani keluarga, tetapi juga berperan penting dalam pendidikan anak-anaknya, terutama dalam melaksanakan pendidikan keagamaan. Pendidikan keagamaan tentunya erat kaitannya dengan pendidikan budi pekerti, hal tersebut mutlak diperlukan dalam proses sosialisasi anak untuk berkembang menjadi dewasa.

Panil yang berkaitan dengan peranan wanita masa Jawa kuno meliputi beberapa panil. Tiga di antaranya menarik untuk dianalisis dalam konteks peran penting wanita dalam pendidikan keluarga dan keagama-an abad ke $9-10 \mathrm{M}$. Berikut akan diulas ke tiga panil tersebut, yaitu.

\section{Panil bernomer 27}

Keluarga pendeta menerima kunjungan wanita dengan abdinya yang membawa bunga.

\section{Panil bernomer 36}

Dilukiskan, dua orang wanita datang ke kediaman pendeta, sambil mempersembahkan bunga. Pendeta itu duduk di dalam bangunan beratap menyerupai atap candi. Adegan berikutnya, tiga orang desa menerima derma dari pendeta yang sedang melakukan perjalanan, serta membawa payung.

\section{Panil bernomer 38}

Di bawah bangunan beratap, seorang tokoh suci memberikan weja-ngan kepada empat wanita yang datang mengunjunginya. Terlihat pula, rakyat datang berduyun-duyun menemui pendeta di tengah hutan.

Pendeta dan Bhiksu pada masa itu memegang peran penting dalam aspek kehidupan masyarakatnya. Selain sebagai tokoh keagamaan yang selalu memimpin aktivitas religius, rupanya juga menjadi bermacam sum- 
ber pengetahuan kebenaran dalam kehidupan bermasyarakat. Hal tersebut dibuktikan dengan banyaknya anggota masyarakat yang datang mengunjungi untuk berkonsultasi dan meminta nasehat-nasehat tentang ajaran kebenaran.

Dari tiga buah panil, salah satunya memuat (no. 27) peran seorang wanita bangasawan yang mengunjungi pendeta sambil membawa bunga (simbolis dari persembahan ?). Hal tersebut menunjukkan wanita bangsawan juga berperan dalam melakukan pembinaan, bimbingan terhadap anak-anaknya. Sebagai seorang bangsawan wanita tidak terlepas dari kodratnya, ia harus mendidik anak-anaknya, apalagi kehidupan para bangsawan selalu menjadi perhatian masyarakat di sekelilingnya. Oleh karena itu ia harus banyak menimba pengetahuan dan meminta bimbingan, nasihat dari para pendeta atau bhiksu agar dapat memberikan tuntunan yang benar bagi anak-anaknya. Hal tersebut juga disebabkan karena tuntutan keluarga. Sebagai orang terpandang harus berlaku benar dan mempunyai kelebihan, utamanya dituntut kemampuan intlektual yang lebih tinggi dibandingkan dengan golongan/lapisan sosial di bawahnya.

Pada panil nomer 36, menggambarkan dua orang wanita datang ke kediaman pendeta dengan membawa bunga. Sebagaimana telah disinggung di atas seorang pendeta selain tugas utamanya menyebarkan agama dan kebenaran juga menjadi tempat 'berkonsultasi' mengenai masalah-masalah pelik yang dihadapi masyarakat sekitarnya baik masalah keluarga maupun masalah keagamaan. Hal tersebut menunjukkan peranan penting seorang pendeta atau bikhsu sudah diterima dengan baik oleh masyarakatnya. Seringnya menemui para pendeta dan bhiksu berkaitan erat dengan adat-istiadat yang sudah ada sebelumnya, sehingga sering menimbulkan permasalahan yang tidak bisa dipecahkannya sendiri, dan mereka memintà bantuan kepada para tokoh keagamaan.

Budaya pada masa itu masih dominan adat-istiadat yang diikuti oleh masyarakat pendukungnya (folkways) (Suyono Ariyono, 1985:124) sebagai peninggalan dari sistem kepercayaan yang ada sebelum masuknya agama Budha. Oleh karena itu dituntut peran aktif dari para pendeta dan bhiksu untuk menjelaskan perbedaan dan persamaan paham-paham (kepercayaan) lama yang masih ada. Peran aktif tersebut tidak sepihak, artinya mendapat sambutan dari seluruh lapisan masyarakat.

Pada panil nomer 38 , terlihat seorang tokoh suci sedang memberi wejangan kepada empat wanita. Tokoh suci tersebut melakukannya di dalam bangunan beratap, sementara itu dalam adegan kedua pada panil 
tersebut, rakyat terlihat berduyun-duyun menemui pendeta di tengah hutan. Ada pasangan suami isteri dengan mengendong anaknya, dan ada pula dua wanita dengan seorang pria yang lebih dahulu mendatangi. Rupanya wejangan dilakukan oleh para pendeta tidak saja dalam waktuwaktu tertentu, tetapi mereka selalu siap melayani dimana pun mereka berada, dan tidak terbatas pada golongan tertentu (bangsawan, raja), tetapi juga bagi seluruh lapisan masyarakat.

\section{Makna Tiga Relief Adegan Karmawibhangga}

Menyimak adegan dari tiga panel yang dilukiskan pada dinding kamadhatu candi Borobudur menarik untuk dibahas lebih lanjut. Satu sisi dilukiskan bahwa masyarakat Jawa kuno sangat aktif dalam mempelajari dan keingintahuannya akan ajaran kebenaran keagamaan yang pada waktu itu masih dianggap baru. Hal tersebut tentunya berkaitan dengan sistem kepercayaan sebelumnya yang dianut, dengan masuknya agama Budha mereka antusias untuk mengikuti dan mempelajarinya. Di sisi lain menunjukkan peranan pendeta/bhiksu cukup penting di dalam segala aspek kehidupan masyarakat. Terlihat peran aktif dari anggota masyarakat, baik golongan bangsawan sampai ke rakyat jelata, laki-laki dan perempuan dan bahkan anak-anak pun ikut pula diajak oleh orang tuanya untuk menemui pendeta/bhiksu. Hal tersebut tentunya sesuatu yang bersifat positif, sejak anak-anak mereka sudah dibiasankan untuk menda-lami hal-hal yang berkaitan dengan ajaran kebenaran dan pelajaran budi pekerti bagi proses sosialisasi anak-anak.

Diperoleh kesan tanggung jawab keluarga seluruhnya tergantung dari kaum laki-laki, tetapi kalau diamati dari tiga relief adegan karma-wibhangga tersebut, kesan itu akan hilang. Secara eksplisit dilukiskan bahwa monopoli tidak hanya bagi kaum laki-laki, tetapi juga bagi kaum wanita. Pada waktu-waktu tertentu wanita-wanita Jawa kuno menemui para pendeta/bhiksu baik di wihara maupun di tengah-tengah hutan. Me-reka datang tidak sekedar menemui, melainkan juga untuk 'berkonsultasi' segala persoalan hidup dan keluarga yang mereka hadapi. Semua itu dilakukan demi masa depan anak-anaknya, sehingga saat dewasa mereka sudah mempunyai dasar kepercayaan dan iman ajaran-ajaran Budhis.

Wanita memegang peranan penting dalam pendidikan dan perkembangan jiwa anak dalam proses sosialisasinya. Proses sosialisasi bersangkutan dengan proses belajar kebudayaan dan berhubungan dengan sistem sosial. Proses itu dilakukan sejak masa kanak-kanak hingga ma-sa 
tuanya dalam belajar pola-pola tindakan dan interaksi dalam kehidup-an sosial yang ada dalam kehidupan sehari-hari (Koentjaraningrat, 1983: 232). Proses belajar mengajar berawal dari keluarga, selanjutnya mema-suki dunia belajar formal. Oleh karena itu para wanita Jawa kuno sadar, bahwa tanggung jawab pendidikan dan perkembangan jiwa anak-anaknya menjadi tanggung jawabnya. salah satu usaha untuk melengkapi adalah dengan bertanya kepada tokoh-tokoh masyarakat, dalam konteks ini salah satunya memilih kaum pendeta/bhiksu. Mereka berkeyakinan to-koh keagamaan dapat memberikan nasehat, bimbingan, dan menjadi to-koh 'panutan'.

Pendidikan anak menurut Philip $\mathrm{H}$. Comb diklasifikasikan menjadi tiga macam, yaitu (Sudarmadi. S,1973:40).

(1). Pendidikan informal, ialah pendidikan yang diperoleh seseorang dari pengalaman sehari-hari dengan sadar atau tidak sadar, sejak seo-rang lahir sampai mati, dalam keluarga, pekerjaan atau pergaulan seharihari.

(2). Pendidikan formal, yaitu pendidikan sekolah yang teratur, bertingkat, dan mengikuti syarat-syarat yang jelas dan ketat.

(3). Penddidikan nonformal, ialah pendidikan yang teratur, dengan sadar dilakukan tetapi tidak terlalu mengikuti peraturan-peraturan yang te-tap dan ketat.

Pendidikan di sini ditekankan pada pendidikan informal dan pendidikan non-formal. Dalam aktivitas pendidikan keluarga masyarakat Jawa kuno tidak terlepas dari pendidikan yang diberikan oleh kaum wanita (kaum ibu) kepada anak-anaknya. Dari ketiga relief terlihat bagaimana peranan para wanita pada masa itu. Hal tersebut tentunya tidak mengesam-pingkan peran penting kaum laki-laki, justru ada semacam kerjasama dan persamaan hak di dalam keluarganya.

Pengetahuan kaum wanita yang diperoleh dari para pendeta akan menjadi bahan acuan pendidikan informal maupun pendidikan nonformal di dalam keluarganya. Hal tersebut dapat dipandang sebagai suatu lem-baga pendidikan tertua. Peranan penting pendidikan sudah menjadi ke-butuhan yang elementer bagi masyarakat Jawa kuno. Disadari maupun tidak ternyata hal tersebut dapat menanamkan nilai-nilai positif bagi ge-nerasi berikut dan selalu hidup dan berkembang di masyarakatnya. Buk-ti-bukti dari keberhasilan pendidikan yang dilakukan oleh kaum wanita masa lalu, masih terasa sampai kini dengan pentingnya peranan ibu da-lam melakukan pendidikan anak di dalam lingkungan keluarga. Secara sadar 
atau tidak ternyata pendidikan tersebut berkembang menjadi pen-didikan budi pekerti, yang manfaat serta kegunaannya dapat dirasakan oleh anakanak dan para orang tua.

\section{Penutup}

Studi relief candi-candi sebenarnya sangat menarik untuk dikaji, ti-dak saja dari salah satu aspek yakni pendidikan anak dan peranan wani-tanya, tetapi juga dari sudut sistem organisasi sosial, teknologi, ilmu pengetahuan, dan kesenian.

Berdasarkan ketiga relief dan beberapa panil adegan karmawibhangga dapat dihipotesiskan; pada masa kejayaan agama Budha di Pulau Jawa peranan wanita menduduki peranan yang penting, terutama kedudukan dalam keluarga, peranan sosial, dan pendidikan anak-anaknya. Keluarga merupakan institusi sosial yang bersifat universal dan multifungsional. Fungsi pengawasan, sosial, pendidikan, keagamaan, perlindungan dan rekreasi dilakukan oleh keluarga terhadap anggota-anggotanya (Vemberiarto, 1987:38).

Seorang wanita selain aktivitas sehari-harinya dalam keluarga juga menyempatkan menimba pengetahuan ajaran-ajaran dan dogma yang digariskan ajaran budhis. Kasus tersebut tidak berbeda dengan kondisi masyarakat Jawa pada masa kini, wanita dalam hal tertentu memegang peranan penting. Selain membantu ekonomi keluarga, juga berusaha meningkatkan pengetahuannya untuk kesejahteraan keluarga, karena hanya pada keluarga dan anak-anaklah sejarah hidup umat manusia akan terus berlangsung untuk mencapai kesejahteraan. Figur wanita tidak terlepas dari kodrat alami yakni kelembutan yang dapat diberikan kepada anakanaknya. Media melalui figur wanita itulah merupakan sarana yang baik untuk melakukan pendidikan di dalam keluarga. Aktivitas tersebut dilakukan oleh para wanita Jawa kuno sejak abab ke 9 dan $10 \mathrm{M}$. 


\section{KEPUSTAKAAN}

Ariyono, Soyono, 1985. Kamus Antropologi Akademika Pressindo, Jakarta

Badil Rudi \& Nurhadi Rangkuti (ed),1989.Rahasia Di Kaki Borobudur Katalis, Jakarta.

Koentjaraningrat, 1974.Kebudayaan Mentalitet Dan Pembangunan PT. Gramedia, Jakarta.

-------, 1983.Pengantar IImu Antropologi, Aksara Baru, Jakarta.

Santiko,Hariani, 1989.Karmawibhangga, Rahasia Dari Jawa Kuno. Rahasia Di Kaki Borobudur, Katalis, Jakarta.

Sudarmadi,S, 1973. Pendidikan Non Formal Dalam Rangka Pengembanngan Sumber Tenaga Usia Muda, Prisma no 5, Tahun ke II. LP3ES, Jakarta.

Vembriarto,ST, 1987.Sosiologi Pendidikan, Paramita,Yogyakarta. 